\title{
AORTIC VALVULAR STENOSIS WITH COARCTATION OF THE AORTA \\ WITH SPECIAL REFERENCE TO THE DEVELOPMENT OF AORTIC STENOSIS UPON CONGENITAL BICUSPID VALVES
}

BY

\author{
D. E. SMITH* AND M. B. MATTHEWS
}

From the Cardiac Department, St. Thomas's Hospital

Received August 21, 1954

The combination of coarctation of the aorta and aortic valvular stenosis is not well known, although the association of coarctation with aortic incompetence is generally recognized and usually attributed to an incompetent bicuspid aortic valve. Abbot (1928), in her review of coarctation, did not discuss its association with aortic valvular stenosis. However, she reported four cases of sub-aortic stenosis occurring with coarctation (an incidence of $2 \%$ ), and Taussig (1947) regards this combination as occurring so frequently as to constitute a clinical entity. Wood (1950) states briefly that with coarctation " aortic or sub-aortic stenosis is by no means rare." Reifenstein et al. (1947) in their series of 104 post-mortem cases of coarctation record 11 with "calcific aortic stenosis" (each of which they regard as being due to rheumatic disease), but they do not enlarge upon this association. Recently Jacobson et al. (1953) have collected 14 reported cases of "calcific aortic stenosis" complicating coarctation, and add one further case; they comment on the surprising rarity of bicuspid aortic valves, which they found in only 3 of 14 necropsy cases [one (Gilbert et al., 1950) lacks post-mortem confirmation], and on the rarity of calcific aortic valves.

Five cases of aortic stenosis complicating coarctation have recently come to our attention. This has prompted a review, from which we have collected 24 cases with necropsy confirmation of this combination.

\section{Clinical Material}

(A) Present Series. Five new cases of coarctation of the aorta with aortic valvular stenosis are reported; three of these have necropsy confirmation, the other two are living.

Case 1. Man, aged 43. A murmur was discovered on routine physical examination at school at 8 years. He was refused life insurance at 17 years, and high blood pressure was found at 22 years. For two years before admission he had complained of giddiness, sweating, and nervousness. On examination there was a systolic thrill and harsh systolic murmur in the second right intercostal space. The second aortic sound was normal. No diastolic aortic murmur was heard, but a mid-diastolic murmur was audible at the apex. A systolic murmur was heard over the back. The radial pulses were equal and the femoral pulses were weak and delayed. The blood pressure was 170/100 in both arms. A cardiogram showed left ventricular hypertrophy and auricular fibrillation. X-ray and screening revealed marked left ventricular enlargement, prominent ascending aorta, extensive rib-notching, but no left auricular enlargement. The patient died of a cerebral vascular accident with a left hemiplegia.

Necropsy. Severe coarctation immediately distal to the origin of the left subclavian artery, which admitted only a surgical needle. There was a marked collateral circulation. The pericardium was unusually

\footnotetext{
* During tenure of Beaverbrook Scholarship from McGill University.
} 
thin. Both auricles were free from clot. The aortic valve was stenosed, with large calcified irregular cusps, and the left ventricle was hypertrophied. There was no mitral stenosis. There was a large embolus at the bifurcation of the right common carotid artery, apparently blocking both internal and external branches. Another embolus occluded the left internal carotid. There was infarction of the posterior part of the right internal capsule and of some of the right occipital lobe. The left kidney had numerous infarcts. A section of the ileum was gangrenous.

Microscopical sections of the aortic and mitral valves were not made. There was thickening of the pericardium over the auricle, and of the endocardial lining. The ventricle showed thickening of the endocardium and atheroma of the coronary arteries. Section of the heart muscle through the auriculo-ventricular junction showed perivascular fibrosis of the small vessels with persisting cellular elements.

Final diagnosis. Coarctation of the aorta, calcific aortic stenosis, multiple emboli, the source of which was not found, and possible rheumatic heart disease.

Case 2 (Dr. Goodwin's case). Woman, aged 18 years. She complained of dyspnœa on effort for six months. There was a systolic thrill and murmur, maximal in the second right intercostal space. The apex beat was heaving and of left ventricular type. The blood pressure was 190/120 in both arms. The femoral pulses were feeble and delayed. A cardiogram showed marked left ventricular hypertrophy. X-ray and screening showed left ventricular enlargement, a small aorta, and rib-notching. The patient died four hours after a resection of the coarctation from hæmorrhage at the suture line.

Necropsy. Bicuspid aortic valve, cusps thickened and orifice stenosed. Marked left ventricular hypertrophy. Microscopic sections from the various valves, valve rings, and left ventricle showed no signs of carditis.

Final diagnosis. Coarctation of the aorta and congenital bicuspid aortic valve with valvular stenosis.

Case 3 (Dr. Bret's case). Man, aged 18 years. A murmur was first discovered at eight years. At 12 years coarctation of the aorta was diagnosed. Dyspnœa had been noted from the age of ten. There had been two episodes of hæmoptysis within two years of death. On examination there was an aortic thrill and murmur, maximal in the second right intercostal space; the murmur was not heard in the neck. There was no aortic diastolic murmur, and no apical murmurs. The blood pressure was 125/? in both arms. The radial pulses were equal, the femoral pulses absent. A cardiogram showed left ventricular hypertrophy. $\mathrm{X}$-ray and screening showed a prominent ascending aorta, and left ventricular hypertrophy. There was no rib erosion. The patient died at the time of aortography.

Post-mortem findings. Coarctation of the aorta close to the subclavian artery, admitting only a stilette. In addition there was stenosis of the aortic orifice with a bicuspid aortic valve and dilatation of the ascending aorta. There were no other cardiac malformations. No microscopical sections were made.

Final diagnosis. Coarctation of the aorta and congenital bicuspid aortic valve with valvular stenosis.

Case 4. Man, aged 52. Rheumatic fever at 6 years. Increasing effort dyspnœa for a year before admission, culminating in attacks of paroxysmal dyspnœa. On examination the apex beat was in the sixth space at the anterior axillary line. There was a harsh systolic murmur over the præcordium, loudest in the second right interspace, and propagated to the neck. There was also an aortic diastolic murmur and a mitral diastolic murmur. The femoral pulses were strong but collateral circulation apparent. The blood pressure was 290/90 on admission and 190/70 four days later. There were basal crepitations. A cardiogram showed complete heart block and right bundle branch block. On X-ray and screening there was cardiac enlargement, pulmonary congestion, rib notching, and a calcified aortic valve. A Wassermann reaction was negative. The patient responded to treatment for heart failure and was discharged.

Clinical diagnosis. Coarctation of the aorta, calcific aortic stenosis and aortic insufficiency, congestive failure, and ? mitral stenosis.

Case 5 (Dr. Goodwin's case). Man, aged 55 years. He had been aware of heart disease since childhood, but there was no history of rheumatic fever or chorea. He had always noted shortness of breath on exertion, which had increased since pneumonia three years previously. The admission to hospital was due to a further attack of pneumonia. On examination there was a systolic murmur, loudest in the aortic area, and a soft aortic diastolic murmur. There was a moderate systolic murmur and a soft rumbling mid-diastolic murmur at the apex. The blood pressure was 170/60 in both arms, and 110/50 in the legs. A collateral circulation was evident. There were basal crepitations. A cardiogram showed marked left ventricular hypertrophy and intra-cardiac block. On X-ray and screening there was gross left ventricular enlargement, calcification of the aortic valve, and marked dilatation of the ascending aorta and arch. The patient was discharged after treatment for the congestive cardiac failure. 
Clinical diagnosis. Coarctation of the aorta, calcific aortic stenosis and incompetence, congestive failure, and ? mitral stenosis.

(B) Cases reported by Other Authors. With Necropsy. Table I records 24 cases of coarctation accompanied by aortic stenosis as the only valvular lesion. In many of the later cases the microscopic findings have been recorded by the original observers in some detail, and therefore permit an opinion as to the ætiology of the valve lesion; in the earlier cases there was no reason to question the conclusions of the original authors. Only one (Case 25) had an "infantile" rather than an adult type of coarctation.

Without Necropsy. Several cases of this syndrome have been reported, without necropsy control. Grishman et al. (1947) report one with aortic stenosis associated with coarctation (their Case 6) and two with other anomalies of the aortic arch (their Cases 2 and 5). Gilbert et al. (1950) report the case of a man, aged 52, with the history of an aortic valve lesion at least since the age of thirty: there was no history of rheumatic fever, and the clinical evidence of coarctation was unequivocal; aortic stenosis was diagnosed on the basis of a systolic murmur and thrill, and calcification of the aortic valve was seen radiologically. It is interesting to note that the blood pressure had been high at the age of $12(160 / 95)$, when the patient was refused life insurance; in later life it was recorded as relatively normal in the arms.

Marquis (1954) has recently reported two cases of this syndrome.

Two of our cases are based on clinical findings; each had calcification of the aortic valve on screening.

\section{Discussion}

As would be anticipated in coarctation (and also in aortic valvular disease), the males outnumber the females, 4 to 1. This is the proportion that Abbott (1928) found in her 200 cases of coarctation.

The average age at death was 38 years. Reifenstein et al. (1947), in their review of 104 autopsied cases of coarctation, found the average age at death to be 35 years. They considered that those patients with complicating valvular disease usually died of congestive failure, and at a later age than those who died of other cardiovascular complications (aortic rupture, cerebral hæmorrhage, and bacterial endocarditis or aortitis). The natural history of these patients appeared to be that of valvular disease rather than of coarctation.

In the present series bicuspid aortic valves were recorded in 20 of 27 cases, an incidence of 74 per cent. This is almost three times the incidence found by Abbott (1928) $(25 \%)$, and nearly twice that found by Reifenstein et al. $(42 \%)$ in their respective series of cases of coarctation.

In the earlier cases it is not possible to determine whether the bicuspid valves were acquired or congenital. Of the six where adequate microscopical details are given, five had a congenital bicuspid valve. In each case aortic valvular stenosis had developed without any gross or microscopical evidence of rheumatic heart disease. Calcification was recorded in three of these. In one case with adequate microscopical detail calcific aortic stenosis had developed on an acquired bicuspid valve. Calcification was described in 14 cases.

It is generally accepted that it may be difficult to decide, even with detailed microscopical examination, whether rheumatic valvulitis has played a part in producing stenosis of a bicuspid aortic valve. In this respect a report that microscopical evidence of rheumatism was absent was considered particularly significant.

It appears that the association of aortic valvular stenosis with coarctation of the aorta has been largely overlooked. Abbott (1928), in her review of 200 cases, reported only two as having aortic valvular stenosis. A re-examination of the original reports upon which her review was based shows that in a further 11 cases aortic valvular stenosis was described, making an incidence of 6.5 per cent in her series.

A bicuspid aortic valve appears to be about twice as common when aortic valvular stenosis complicates coarctation of the aorta as in a general series of coarctation. 
TABLE I

Post-mortem Cases of Aortic Valvular Stenosis complicating Coarctation of the Aorta*

\begin{tabular}{|c|c|c|c|c|c|c|}
\hline \multirow{2}{*}{$\begin{array}{l}\text { Case } \\
\text { No. }\end{array}$} & \multirow{2}{*}{ Author } & \multirow{2}{*}{ Sex } & \multirow{2}{*}{ Age } & \multicolumn{2}{|c|}{ Aortic valve } & \multirow{2}{*}{ Remarks } \\
\hline & & & & Orifice & Cusps & \\
\hline $\begin{array}{l}1 \\
2 \\
3\end{array}$ & $\begin{array}{l}\text { Craigie, Case } 9(1841) \\
\text { Peacock, Case } 24(1860) \\
\text { Peacock, Case } 27(1860)\end{array}$ & $\begin{array}{l}\mathbf{M} \\
\mathbf{F} \\
\mathbf{M}\end{array}$ & $\begin{array}{l}27 \\
20 \\
14\end{array}$ & $\begin{array}{l}\text { Constricted }{ }^{*} \dagger \\
\text { Contracted } \\
\text { Somewhat } \\
\text { narrow }\end{array}$ & $\begin{array}{l}\text { Calcified } \\
\text { Bicuspid } \\
\text { Bicuspid** }\end{array}$ & Patent ductus arteriosus \\
\hline $\begin{array}{l}4 \\
5\end{array}$ & $\begin{array}{l}\text { Peacock, Case } 29(1860) \\
\text { Barié, Case } 58(1886)\end{array}$ & $\underset{\mathbf{F}}{\mathbf{M}}$ & $\begin{array}{l}32 \\
19\end{array}$ & $\begin{array}{l}\text { Narrow } \\
\text { Very stenosed }\end{array}$ & $\begin{array}{l}\text { Immovable } \\
\text { Bicuspid }\end{array}$ & Widely patent ductus \\
\hline 6 & Barié, Case 78 (1886) & $\mathbf{M}$ & 65 & $\begin{array}{l}\text { Considerable } \\
\text { stenosis }\end{array}$ & $\begin{array}{l}\text { Bicuspid; calci- } \\
\text { fied }\end{array}$ & arteriosus \\
\hline $\begin{array}{l}7 \\
8\end{array}$ & $\begin{array}{l}\text { Barié, Case } 70(1886) \\
\text { Bonnet, Case } 14(1903)\end{array}$ & $\begin{array}{l}\mathbf{M} \\
\mathbf{M}\end{array}$ & $\begin{array}{l}38 \\
25\end{array}$ & - & $\begin{array}{l}\text { Bicuspid } \\
\text { Bicuspid }\end{array}$ & $\begin{array}{l}\text { Cusps partially fused } \\
\text { Anterior cusp rigid and } \\
\text { calcified }\end{array}$ \\
\hline 9 & Bonnet, Case 25 (1903) & $?$ & $?$ & $\begin{array}{r}\text { Stenosed and } \\
\text { incompetent }\end{array}$ & - & $\begin{array}{l}\text { Aortic aneurysm distal } \\
\text { to coarctation }\end{array}$ \\
\hline 10 & Fawcett, Case 3 (1905) & F. & c. 45 & Stenosed & Biscupid & Patent ductus arteriosus \\
\hline 11 & Fawcett, Case 10 (1905) & $\mathbf{F}$ & 34 & Stenosed & $\begin{array}{l}\text { Bony cretaceous } \\
\text { vegetations }\end{array}$ & $\begin{array}{l}\text { Miniature supernu- } \\
\text { merary cusp } \frac{1}{4} \text { in. above } \\
\text { valve; bacterial endo- } \\
\text { carditis }\end{array}$ \\
\hline 12 & Hamilton and Abbott (1920) & $\mathbf{M}$ & 14 & $\begin{array}{c}\text { Stenosed and } \\
\text { incompetent }\end{array}$ & Bicuspid** & $\begin{array}{l}\text { Sub-aortic stenos is; } \\
\text { dissecting aneurysm of } \\
\text { aorta: adherent peri- } \\
\text { cardium }\end{array}$ \\
\hline 13 & Abbott (1928) quotes Reinitz (1902) & $\mathbf{M}$ & 34 & Stenosed & $\begin{array}{l}\text { Bicuspid**; calci- } \\
\text { fied }\end{array}$ & \\
\hline 14 & Rösler (1928) & $\mathbf{M}$ & 45 & Severe stenosis & Bicuspid & \\
\hline 15 & Bode and Knop (1928) $\ddagger$ & $\mathbf{M}$ & 54 & Stenosed & $\begin{array}{l}\text { Bicuspid**; calci- } \\
\text { fied }\end{array}$ & \\
\hline 16 & Hein (1931) & $\mathbf{M}$ & 60 & Stenosed & $\begin{array}{l}\text { Calcified; "valve } \\
\text { incomplete" }\end{array}$ & \\
\hline 17 & Bishop and Trubek (1936) & $\mathbf{M}$ & 45 & Narrow slit & $\begin{array}{l}\text { Bicuspid; calci- } \\
\text { fied }\end{array}$ & $\begin{array}{l}\text { Ductus partially obli- } \\
\text { terated. Microscopical } \\
\text { examination suggested } \\
\text { inflammatory fusion of } \\
\text { aortic cusps }\end{array}$ \\
\hline 18 & Benkwitz and Hunter (1937) & $\mathbf{M}$ & 37 & Stenosis & $\begin{array}{l}\text { Bicuspid (prob- } \\
\text { ably congenital); } \\
\text { calcified }\end{array}$ & $\begin{array}{l}\text { Sub-aortic stenosis; } \\
\text { calcified }\end{array}$ \\
\hline 19 & Ingham (1939) & $\mathbf{M}$ & 50 & Severe stenosis & $\begin{array}{l}\text { Congenital } \\
\text { bicuspid }\end{array}$ & $\begin{array}{l}\text { Microscopically no } \\
\text { evidence of inflamma- } \\
\text { tion }\end{array}$ \\
\hline 20 & Gitlow and Sommer (1940) & $\mathbf{M}$ & 45 & Severe stenosis & $\begin{array}{l}\text { Bicuspid (prob- } \\
\text { ably congenital); } \\
\text { calcified }\end{array}$ & $\begin{array}{l}\text { Microscopically no } \\
\text { evidence of syphilis or } \\
\text { rheumatic heart disease }\end{array}$ \\
\hline 21 & Lewis (1945) & $\mathbf{M}$ & 38 & Stenosed & $\begin{array}{l}\text { Congenital } \\
\text { bicuspid; } \\
\text { calcified }\end{array}$ & $\begin{array}{l}\text { Microsco pically no } \\
\text { evidence of an acquired } \\
\text { union between the } \\
\text { cusps }\end{array}$ \\
\hline 22 & Clark and Firminger (1949) & $\mathbf{M}$ & 32 & Stenosed & $\begin{array}{l}\text { Congenital } \\
\text { bicuspid; } \\
\text { calcified }\end{array}$ & $\begin{array}{l}\text { Microscopically no } \\
\text { evidence of fibrosis or } \\
\text { inflammation }\end{array}$ \\
\hline 23 & Jacobson et al., Case 3 (1953) & $\mathbf{M}$ & 38 & Stenosed & $\begin{array}{l}\text { Bicuspid**; calci- } \\
\text { fied }\end{array}$ & \\
\hline 24 & Brown (1934) & F & $\begin{array}{c}3 \\
\text { days }\end{array}$ & Severe stenosis & $\begin{array}{l}\text { A fibrous } \\
\text { diaphragm }\end{array}$ & $\begin{array}{l}\text { Microscopically no } \\
\text { endocarditis. Congen- } \\
\text { ital stenosis }\end{array}$ \\
\hline $\begin{array}{l}25 \\
26\end{array}$ & Present series, Case 1 & $\mathbf{M}$ & 43 & Severe stenosis & Calcified & \\
\hline 26 & Present series, Case 2 & $\mathbf{F}$ & 18 & Slight stenosis & $\begin{array}{l}\text { Congenital } \\
\text { bicuspid }\end{array}$ & $\begin{array}{l}\text { Microscopically no } \\
\text { rheumatic heart disease }\end{array}$ \\
\hline 27 & Present series, Case 3 & $\mathbf{M}$ & 18 & Severe stenosis & Bicuspid** & \\
\hline
\end{tabular}

* In each case the aortic lesion was the only valvular lesion reported. The opinions recorded are those of the original authors. ** Probably congenital.

$\dagger$ Also reported by Peacock (1860, Case 9$)$.

$\ddagger$ This case was more fully reported by Weber and Knop (1929).

$\mathbf{P}$ 
The AEtiology of Aortic Stenosis associated with Coarctation of the Aorta. Brown (1934) described the case of an infant dying three days after birth who had congenital aortic valvular stenosis, coarctation of the aorta, a widely patent ductus arteriosus, and a patent foramen ovale. "There was a fibrous diaphragm at the site of the aortic valves-this was thick and hard and was pierced by a minute opening. The cusps could not be differentiated." There was no evidence that the stenosis of the aortic orifice was due to a fætal endocarditis. Brown concludes: "A search of the literature has failed to reveal one (case) in which orificial stenosis of the aorta was combined with isthmus stenosis." In this he presumably refers to congenital orificial stenosis.

Brown's appears to be the only case in which congenital aortic stenosis was associated with coarctation of the aorta. It is apparent from the above autopsy reports (Table I) that aortic valvular stenosis, when complicating coarctation of the aorta, is an acquired lesion, though this does not exclude the possibility of an underlying malformation. However, Bishop and Trubeck (1934) conclude that the presence of an associated congenital cardiovascular anomaly, such as coarctation of the aorta, cannot be taken as presumptive evidence that the calcified aortic stenosis has developed on a malformed valve. Fawcett (1905), in a review of 18 cases of coarctation, stated that "The constant strain to which the aortic valves are subjected leads in the majority of cases to a chronic inflammatory change with the result that the valves become thickened, or adherent, or the orifice stenosed." He made no mention of bicuspid aortic valves, so that it must be assumed that he was referring to changes in a previously normal valve. Reifenstein et al. (1947) concluded that their 11 cases of aortic stenosis associated with coarctation were all attributable to rheumatic heart disease.

The frequent association of coarctation of the aorta with congenital bicuspid aortic valves has already been noted. Abbott reported a further four, and Reifenstein et al. three cases of apparently acquired bicuspid valves. Conversely, Lewis and Grant (1923) found that coarctation was the commonest malformation associated with undoubted congenital bicuspid aortic valves. A bicuspid aortic valve occurring with coarctation is, therefore, almost always congenital. Jacobson et al. (1953) commented on the rarity of bicuspid valves in this syndrome, but in the present series bicuspid aortic valves were found in 20 of 27 cases (Table II).

\section{TABLE II}

Incidence of Bicuspid Aortic Valves in Coarctation of the Aorta and Aortic Valvular Stenosis

Total number of cases of coarctation and aortic stenosis: 27 Bicuspid valve (1) inflammatory

(2) congenital

(3) probably congenital

(4) undetermined

\begin{tabular}{rrrr}
1 & & & \\
5 & & & \\
7 & & & \\
7 & & & \\
\hline. & $\ldots$ & $\ldots$ & 14 \\
& & & 20 \\
&. &. & 9
\end{tabular}

Bicuspid Aortic Valve as a Basis of Aortic Stenosis. The first worker to remark on the fact that bicuspid semilunar valves are prone to disease appears to have been Paget (1844): "It has never, I believe, been noticed (though there need be no doubt about the fact) that in the majority of cases in which only two valves have been found in the aorta or pulmonary artery, these valves have been diseased and often extremely diseased." Peacock (1851) was among the first to be aware that the high pressure to which the aortic valve is exposed makes it vulnerable to disease. "We know that in after-life the variable pressure of the blood in the arterial system is a fruitful cause of disease in the aortic valves."

These two concepts are of special application in coarctation, where hypertension is almost invariably present and a congenital bicuspid valve common. Peacock also demonstrated clearly that the congenital bicuspid aortic valve could become diseased, and either stenosed or incompetent: 
“. . . the defect described (bicuspid aortic valve) is shown to be of congenital origin, at least in many instances, by its co-existence with other obvious malformations, and by its occurring in children which survive birth only a short period, and even in fœtuses which have never breathed...." (Peacock, 1886, pp. 131 and 132.)

"The forms of the defect (bicuspid valve) now described, though not necessarily interfering with the functions of the heart, do, in a considerable number of cases lay the foundation of disease in after-life." ... "When the whole of the segments are fused together or when two only are united, the valves not infrequently become the seat of chronic inflammation, by which they are rendered thick and unyielding and often become extensively ossified, thus inducing, first obstruction to the flow of blood from the ventricle into the aorta, and then incompetency." (Peacock, 1886, p. 133.)

Earlier, in his Croonian lectures of 1857 , Peacock had expressed views similar to the above, and added: "I believe, however, that when the symptoms and signs of uncomp:icated aortic valvular disease manifest themselves in persons who have never had rheumatic fever or other serious illness, . . . we shall generally be correct in assigning its probable production to malformation of the valves." (Peacock, 1857, p. 31.) From this it is clear that Peacock believed that the bicuspid aortic valve frequently becomes stenosed without superimposed rheumatic valvulitis.

Many workers since Peacock have noted that congenital bicuspid valves usually show secondary changes in the adult. Osler (1886) remarked: "The united cusps may have a perfectly normal appearance, but in adults they are almost invariably thickened and the seat of sclerotic or, in some cases, ulcerative changes ... doubtless the strain on the fused curtains is more severe than upon normal cusps." He commented on the frequency of associated left ventricular hypertrophy.

Lewis and Grant (1923) noted that in congenital bicuspid valves thickenings were " the rule rather than the exception" and occur " as secondary processes in aortic valve margins which fail closely to adjust themselves when the valve shuts." Their investigations included detailed microscopy of bicuspid valves; they regarded these changes as due to faultily functioning valves and not to a rheumatic valvulitis.

Koletsky (1941), in a study of 18 cases of congenital bicuspid aortic valves concluded, "This anomaly also may pre-dispose to calcific sclerosis," and considered that the association of calcific sclerosis and a congenital bicuspid valve was not very rare. Although he does not discuss aortic stenosis in this communication, in one at least of his cases (Case 13) calcific aortic stenosis was superimposed on a congenital bicuspid aortic valve, and there was no microscopic evidence of rheumatic disease in sections of the heart, valve rings, and valves. He also states: "The inherent tendency of the congenital bicuspid valve to undergo degeneration and fibrosis has been pointed out frequently and is attributed to the fact that abnormally developed cusps are composed of imperfect or defective tissue. The degeneration and fibrosis are undoubtedly accelerated with age, and in older persons, particularly those with an especial tendency to arteriosclerosis, would be prone to lead to the deposition of calcium."

In considering the general problem of calcific aortic stenosis, Karsner and Koletsky (1947) concluded that this lesion is almost always of rheumatic origin. Of 200 cases, only four were not associated with rheumatic stigmata. These conclusions were based essentially on microscopical findings. However, Hall and Anderson (1943) have shown that, if the criteria of Gross et al. (1930) are valid for the diagnosis of rheumatic heart disease, the incidence of rheumatic fever is comparable to that of tuberculosis and infantile paralysis. On these grounds the conclusions of Karsner and Koletsky are open to criticism. Kiloh (1950) concluded that a congenital bicuspid valve may well play an important role in the development of calcific aortic stenosis. A similar conclusion is reached by Bailey et al. (1954).

Hall and Ichioka (1940) studied the ætiology of 31 cases of nodular calcific aortic stenosis. They divided these cases into 19 with isolated aortic lesions, and 12 with combined aortic and mitral lesions. Using the standard microscopical criteria for rheumatic disease, they concluded that the 
changes in all the cases appear to have a common ætiology and fulfil the criteria generally accepted for chronic rheumatic infections of the heart. The same criticism of these findings may be made as were made of those of Karsner and Koletsky. In addition, it is of interest to note that in 8 of the 19 cases with isolated aortic valve disease bicuspid valves were found, but " strangely none was found in the mixed group."

It is apparent then, that aortic stenosis can develop on a congenital bicuspid valve independently

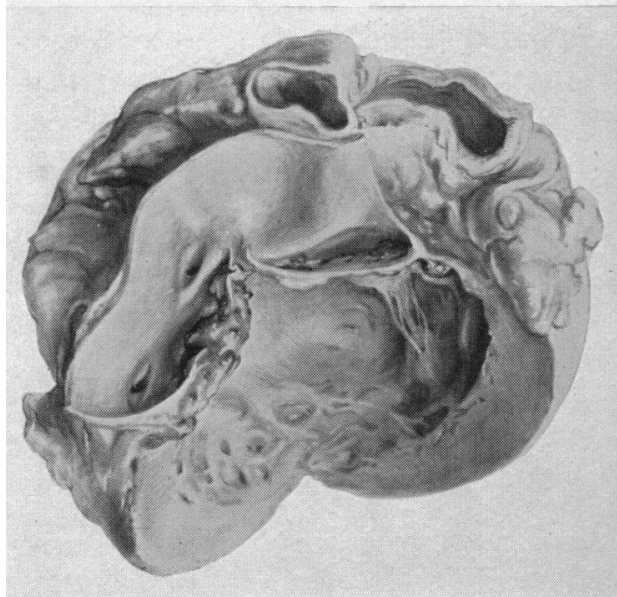

A

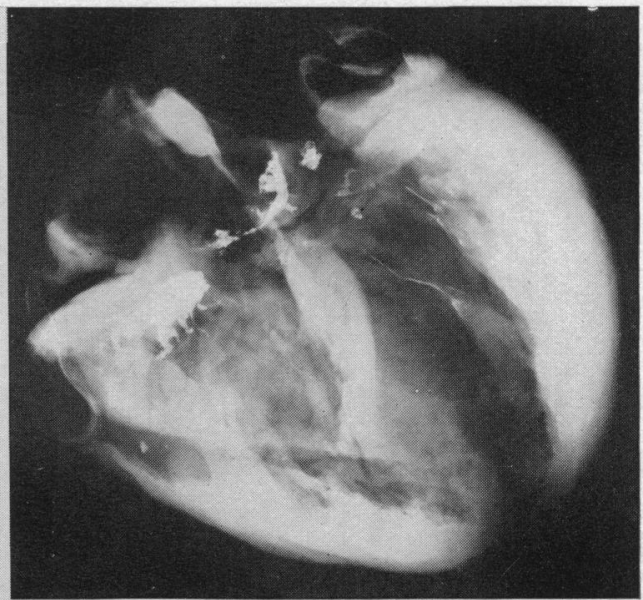

B

FIG. 1.-Drawing (A) and X-ray (B) to show calcification in a congenital bicuspid aortic valve which produced aortic stenosis, in a man, aged 60. It is one of Peacock's specimens in St. Thomas's Hospital Museum (No. 1A.1.28), and was originally reported by Bennett (1851), who described the obstruction to blood flow as being due to rigidity of the cusps. [A rudimentary third valve between the other two can be seen in the specimen and drawing; in Peacock (1886) there is an engraving of the specimen (Plate VII, Fig. 3) where it has been exaggerated.]

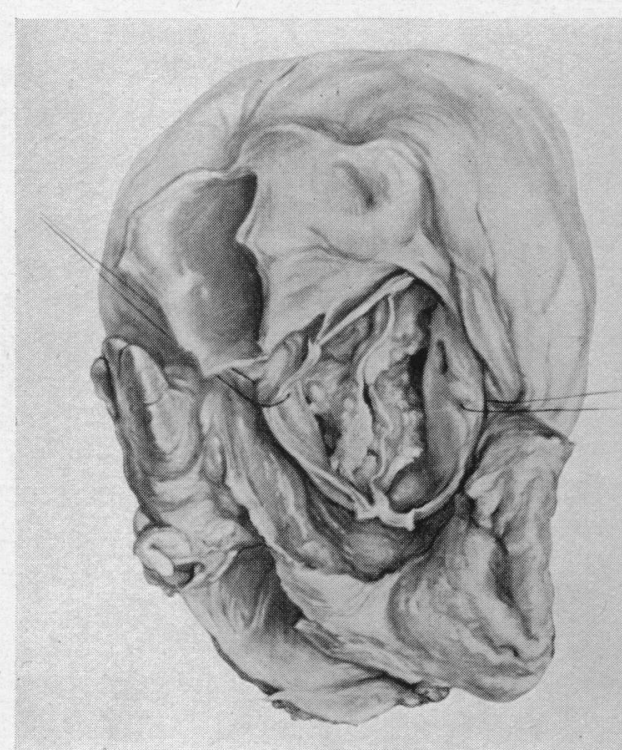

A

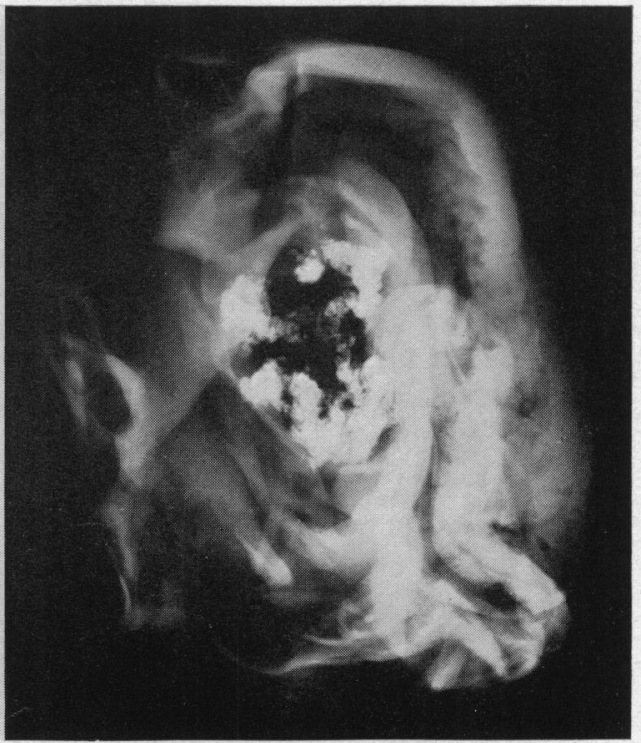

B

FIG. 2.-Drawing (A) and X-ray (B), showing calcification in a congenital bicuspid aortic valve in a man, aged 65, with characteristic signs of aortic stenosis. He died suddenly during treatment for left ventricular failure. Note that the obstruction to blood flow is due to rigidity of the cusps; there is no commissural fusion. The left ventricle was markedly hypertrophied. (St. Stephen's Hospital, Case No. 36309.) 
of rheumatic inflammation. Reifenstein et al. (1947) and Wauchope (1928) have, however, suggested that the congenital bicuspid aortic valve is more prone to rheumatic disease than normallyformed cusps. From the necropsy reports in the present series we suggest that Peacock was correct in concluding that valvular aortic stenosis could arise from degeneration, usually with calcification, in a congenital bicuspid valve. The liability to such changes is increased by the abnormal mechanical stresses of a malformed and malfunctioning valve, and the process hastened by the higher pressures imposed by the coarctation. A similar interpretation of aortic incompetence in coarctation of the aorta with a bicuspid aortic valve is used by Bramwell and King (1942).

Induration and calcification of the cusps, rather than commissural fusion, may be the cause of obstruction at the valve orifice in some cases. Fig. 1 and 2 show the degeneration and calcification that occurred in two congenital bicuspid valves. The first example is of interest in being one of Peacock's own cases from the Museum at St. Thomas's Hospital, and shows extensive calcification in the bicuspid valve of a male, aged 60 . The second is from a man of 65 who died of cardiac failure from aortic stenosis. In neither valve was there evidence of an acquired fusion. In both cases left ventricular hypertrophy demonstrated that there had been obstruction to blood flow at the valve. In each the bicuspid valve occurred as an isolated anomaly.

We conclude, therefore, that aortic stenosis is quite common in coarctation of the aorta, and that a congenital bicuspid valve is the common factor.

We suggest that these conclusions may have a wider implication in accounting for some cases of isolated calcific stenosis of undetermined ætiology. It is possible that some of those patients whose bicuspid aortic valves are not revealed by subacute bacterial endocarditis may present in old age with the signs of aortic stenosis as the first overt evidence of this malformation. Support is lent to this conclusion by the fact that, in old age, aortic stenosis is commoner in men than women.

Often the calcified aortic valve can be seen to be bicuspid, but if the calcification and destruction of the valve are far advanced, as is so frequently the case, a correct morphological interpretation may be impossible and the histological picture confused.

Note on Diagnosis. The clinical diagnosis of aortic stenosis in the presence of coarctation is important now that surgical treatment is possible. Uncomplicated coarctation of the aorta may produce systolic murmurs sufficiently loud to cause a thrill (Reifenstein et al., 1947), and the thrill may disappear after a successful resection of the coarctation (Goodwin, 1954). If the murmur is obviously louder to the right of the sternum than to the left, the possibility of aortic valvular stenosis should be considered.

If there are typical enlarged collateral blood vessels, and a weak and delayed or absent femoral pulse, the finding of a normal blood pressure in the arms is extremely suggestive of co-existing aortic stenosis. Bishop and Trubeck (1936) report the finding of a blood pressure of 110/70 in the upper extremities in a man of 45 with this combination (Case 18, Table I). In Cases 15 and 27 the blood pressure in the arms was also normal. In the clinical case of Gilbert et al. (1950) already noted, the blood pressure in the arms had been raised at the age of $12(165 / 95)$, but was normal 40 years later.

The brachial arterial pressure pulse may be helpful if it shows prolonged systolic ejection or anacrotism, as suggested by Grishman et al. (1947). The differentiation of valvular from subvalvular stenosis is impossible, though calcification visible on $\mathrm{X}$-ray is more suggestive of the former. Evidence of left ventricular hypertrophy on X-ray screening, or from the electrocardiogram is to be expected more frequently than in isolated coarctation.

\section{Summary AND CONCLUSIONS}

Five cases of aortic valvular stenosis combined with coarctation of the aorta are described. In three there was necropsy control, and in the other two radiological evidence of calcification of the aortic valve. A further 24 similar reported cases with necropsy control are reviewed. A re-examination of the original reports upon which Abbott's (1928) review of 200 cases of coarctation were based shows the incidence of aortic valvular stenosis to be 6.5 per cent.

Of the 27 cases with necropsies, 20 had a bicuspid aortic valve. In 5 of the 6 where microscopy 
was adequate, the absence of rheumatic stigmata was taken to indicate that the bicuspid valve was congenital and the stenosis not rheumatic. In a further 7 the original authors considered that the bicuspid valve was congenital, while only one was proved on microscopy to have arisen from fusion of two of three cusps.

It is concluded that Peacock's suggestion that degeneration in a congenital bicuspid valve can lead to aortic stenosis is correct. The frequency of congenital bicuspid valve in association with coarctation, its abnormal structure, and the higher pressures to which in coarctation the aortic valve is exposed, are considered to be the factors responsible for the development of aortic stenosis with coarctation.

It is suggested that the importance of degeneration of the congenital bicuspid valve as a cause of isolated calcific aortic stenosis has not received sufficient attention. This is attributed to the difficulty of morphological interpretation when the deformity and calcification are far advanced.

The clinical features of the syndrome are briefly discussed.

We are grateful to Dr. J. F. Goodwin for putting at our disposal the records of Cases 2 and 4, and to Dr. Jean Bret of Lyons for the details of Case 3; to Dr. Raymond Daley for the specimen shown in Fig. 2; to Dr. A. C. Dornhorst for helpful criticism; to Miss Joan Dewe for the illustrations and to Mr. A. L. Wooding for their reproduction.

\section{REFERENCES}

Abbott, M. E. (1928). Amer. Heart J., 3, 392574.

Bailey, C. P., Bolton, H. E., Jamieson, W. L., and Nichols, H. T. (1954). Circulation, 9, 22.

Barié, E. (1886). Rev. méd., 6, 343, 409, 501.

Benkwitz, K. B., and Hunter, W. C. (1937). Amer. J. Path., 13, 289.

Bennett, R. (1851). Trans. Path. Soc. Lond., 3, 289.

Bishop, L. F., and Truebeck, M. (1934). Amer. J. med. Sci., 188, 506

- (1936). J. Tech. Meth., 15, 111.

Bode, O. B., and Knop, F. (1929). Deutsch. Archiv. Klin. Med., 163, 298.

Bonnet, L. M. (1903). Rev. méd., 23, 108, 255.

Bramwell, C., and King, J. T. (1942). The Principles and Practice of Cardiology. Oxford University Press.

Brown, J. (1934). Lancet, 1, 236.

Clark, R. J., and Firminger, H. I. (1949). New Engl. J. Med., 240, 710.

Craigie, D. (1841). Edn. med. surg. J., 56, 427.

Fawcett, J. (1905). Guy's Hosp. Rep., 59, 1.

Fray, W. W. (1930). Amer. J. Roentgenol., 24, 349.

Gilbert, R. L., Riordan, J. J., and Murphy, J. P. (1950). J. Missouri med. Ass., 47, 333.

Gitlow, S., and Sommer, R. I. (1940). Amer. Heart J., 20, 106.

Goodwin, J. (1954). Personal communication.

Grishman, A., Steinberg, M. F., and Sussman, M. L. (1947). Med. Clin. N. Amer., 31, 543.

Gross, L., Antopol, W., and Sacks, B. (1930). Arch. Path., 10, 840.

Hall, E. M., and Anderson, L. R. (1943). Amer. Heart J., $25,64$.

- and Ichioka, T. (1940). Amer. J. Path., 16, 761.

Hamilton, W. F., and Abbott, M. E. (1928). Amer. Heart J., 3, 381.

Hein, G. E. (1931). U.S. Vet. Bur. Bull., 7, 209.

Ingham, D. W. (1939). N.Y. St. J. Med., 39, ii, 1865.

Jacobson, G., Cosby, R. A., Griffith, G. C., and Meyer, B. W. (1953). Amer. Heart J., $45,889$.

Karsner, H. T., and Koletsky, S. (1947). Calcific Diseases of the Aortic Valve. New York.

Kiloh, G. A. (1950). Brit. Heart J., 12, 33.

Koletsky, S. (1941). Arch. intern. Med., 67, 129, 157.

Lewis, R. B. (1945). Amer. J. Clin. Path., 15, 292.

Lewis, T., and Grant, R. T. (1923). Heart, 10, 31.

Marquis, R. M. (1954). Meeting of British Cardiac Society, Cambridge.

Osler, W. (1886). Trans. Ass. Amer. Phys., 1, 185.

Paget, J. (1844). Trans. Roy. Med-Chir. Soc., 27, 162.

Peacock, T. B. (1851). Trans. Path. Soc. Lond., 3, 291.

(1857). On some of the Causes and Effects of Valvular Disease of the Heart. (Croonian Lectures.) London.

- (1860). Brit. For. Med-Chir. Rev., 25, 467.

(1886). Malformations of the Human Heart. John Churchill \& Sons, London.

Reifenstein, G. H., Levine, S. A., and Gross, R. E. (1947). Amer. Heart J., 33, 146.

Rosler, H. (1928). Wien. Archiv. Inn. Med., 15, 321.

Taussig, N. (1947). Congenital Malformations of the Heart. New York.

Wauchope, G. M. (1928). Quart. J. Med., 21, 383.

Weber, F. Parkes, and Knop, F. (1929). Med. Press, 127, 195.

Wood, P. (1950). Diseases of the Heart and Circulation. Eyre \& Spottiswode, London. 